\title{
The Policy of the Russian Orthodox Church on International Labor Migrants: How the Public Role Collides with Preaching the Word
}

\author{
Anastasia Mitrofanova ${ }^{1,2, *}$, Svetlana Riazanova ${ }^{3}{ }^{-}$and Aleksandr Brega ${ }^{4}$ \\ 1 Institute of Sociology, Federal Center of Theoretical and Applied Sociology, Russian Academy of Sciences, \\ 117218 Moscow, Russia \\ 2 Department of Political Science, Financial University under the Government of the Russian Federation, \\ 117133 Moscow, Russia \\ 3 Perm Federal Research Center, Ural Branch of the Russian Academy of Sciences, 614066 Perm, Russia; \\ svet-ryazanova@yandex.ru \\ 4 Department of Digital Economy and Mass Communications, Moscow Technical University of \\ Communications and Informatics, 111024 Moscow, Russia; a.v.brega@mtuci.ru \\ * Correspondence: avmitrofanova@fa.ru; Tel.: +7-903-553-9007
}

check for updates

Citation: Mitrofanova, Anastasia, Svetlana Riazanova, and Aleksandr Brega. 2021. The Policy of the Russian Orthodox Church on International Labor Migrants: How the Public Role Collides with Preaching the Word. Religions 12: 993. https://doi.org/ $10.3390 /$ rel12110993

Academic Editors:

Victor Roudometof and John Jillions

Received: 8 October 2021

Accepted: 6 November 2021

Published: 12 November 2021

Publisher's Note: MDPI stays neutral with regard to jurisdictional claims in published maps and institutional affiliations.

Copyright: (c) 2021 by the authors. Licensee MDPI, Basel, Switzerland. This article is an open access article distributed under the terms and conditions of the Creative Commons Attribution (CC BY) license (https:/ / creativecommons.org/licenses/by/ $4.0 /)$.

\begin{abstract}
The authors' objective was to find out how and why the approach of the Russian Orthodox Church to sociocultural adaptation of predominantly Muslim international labor migrants has evolved from its initial stage to now. Research methodology is based on a critical analysis of various sources, on observations, and archival materials. The adaptation program of the Church was advertised as a secular project pursuing the goal of peacekeeping because of a tacit agreement on mutual non-proselytisation between the basic faith-based communities in Russia. The initiative, launched in December 2012, had to merge adaptation courses of all dioceses into a nationwide network that then was expected to become part of an all-Russian system of preparation for language and culture tests. The Church also planned to open its own network of testing centrescenters for migrants. The authors emphasize that, although some of the diocesan courses were successful, the initiative deteriorated due to many external and internal factors. One of them was that diocesan courses have proven to be unattractive for labor migrants; their curriculum was too thick and overloaded with information about Russian culture and Orthodox Christianity, while Muslim labor migrants preferred to adapt to their new environment with a mediation of their own networks. It is suggested by the authors that the main cause of the project's non-fulfillment was an intra-church cleavage between the enthusiasts of adaptation who convinced that diocesan courses must aim at spreading the Orthodox faith to foreign workers, including Muslims, and the church officials who promoted secular curriculum and forbade preaching Christianity to labor migrants.
\end{abstract}

Keywords: adaptation of labor migrants; policy of adaptation; Russian Orthodox Church; faith-based organizations; Muslim migrants; adaptation network; migrant networks; Vsevolod Chaplin

\section{Introduction}

In accordance with the UN guidance, we understand international labor migration as the movement of persons from one state to another for the purpose of employment (IOM 2021). The article is focused on labor migrants who make up the majority of immigrants to Russia: by the end of 2020 there had been only 455 refugees and 19,817 seekers of temporary asylum in the country (Tretiyakova 2021); the number of international students as of mid-2021 was around 270,000 (Regnum 2021). At the same time, 2.68 million people were estimated to be international migrant workers in May 2021 (Rambler 2021). This figure is not precise, because it does not include citizens of the member states of the Eurasian Economic Union (Belarus, Armenia, Kazakhstan, and Kyrgyzstan) who currently need no work permissions. 
Most foreign labor migrants (as of the first half of 2019) arrive to Russia from Uzbekistan, Tajikistan, and Kyrgyzstan (Starostina 2019), thus being, at least nominally, Muslim. The Russian population is culturally Christian; according to some estimates, $63 \%$ declare being Orthodox Christians (WCIOM 2019), although mostly non-practicing. Cultural discrepancies between the host society and the newcomers may also result from the gap in the levels of urbanization and development between Russia and its neighbors. Apart from cultural strains, Russian society sometimes envisions foreign labor migrants as stealing jobs, dumping prices at the labor market, and competing with the natives for limited public resources, such as health services and education. These tensions provoke multiple everyday collisions between the locals and the newcomers, which exacerbate their mutual lack of understanding.

Initially, the state paid insufficient attention to sociocultural adaptation of labor migrants and suggested that they should be dealt with by commercial firms, or-in case of illegal immigration - by police forces. It was in 2012 when the Concept of State Migration Policy of the Russian Federation mentioned adaptation of foreign labor migrants as an important public task. Since 2015 foreign labor migrants are to be tested in the Russian language, history, and the foundations of law. Russian scholars agree that adaptation, as opposed to integration or assimilation, means that international migrants learn the norms and values of the host society, preserving, at the same time, their original identities (Drobizheva 2010, p. 90). We suggest that successful adaptation depends on effective intermediaries able to act as tutors, sponsors, or providers of social benefits, and that, like in many other countries, faith-based organizations in Russia have the potential to become facilitators of adaptation.

Assistance to labor migrants (including adaptation) forms a significant share of the social services provided by Orthodoxy-based noncommercial organizations in Russia, but their participation in the process of adaptation has not yet been subject to scholarly attention (except: Curanović 2019; Lunkin 2019). Scholarly literature on sociocultural adaptation of Muslim labor migrants is extensive, but it does not specify the role of the Orthodox Church, which is the largest and the most influential religious organization in Russia (see: Starostin 2011; Riazanova and Chernykh 2012; Vinokurova and Ardalianova 2017; Cherepanova and Maksimova 2019; Olimov and Olimova 2019; Pronina 2020; Ledenyova and Begasilov 2021, etc.); transnational migration with regard to Orthodox Christianity has mostly been researched in the context of Orthodox believers moving to foreign countries (see, for example: Hämmerli and Mayer 2014; Stoeckl 2014; Leustean 2019).

The authors' research objective is to find out how and why the approach of the Russian Orthodox Church (the ROC) to sociocultural adaptation of international labor migrants has evolved from its initial stage to now. Our methodology is based on a critical analysis of the relevant official church documents and statements on sociocultural adaptation, and of various printed and electronic sources that mirror competing intra-church ideological platforms. Besides, in 2012-2014 one of the authors was employed by the church and public project for adaptation of migrants "Enlightenment"; their observations and archival materials have also contributed to our research. Evaluating the attitudes of Muslim migrants toward adaptation, we relied on data obtained through qualitative research conducted in 2011 in the Perm Krai of Russia. Our study was qualitative in nature and implied no collection of quantitative data.

The article is in the analytical framework of "public", or deprivatized religion that, according to Jose Casanova, "enters the undifferentiated public sphere of civil society to take part in the ongoing process of contestation, discursive legitimization and redrawing of the boundaries" (Casanova 1994, p. 65). The Russian Orthodox Church operates, in Casanova's typology, at the civil society level: it is not an established state church, being, at the same time, unable to mobilize religious groups and confessional parties politically. In the situation of religious pluralism, the Church has to articulate its positions on important public issues having in mind not only the state as a dominating partner, but also the interests of other faith-based actors present in the public sphere. This leaves no option but 
accepting "the inviolable right to privacy and the sanctity of the principle of freedom of conscience" (ibid., p. 57) and, in fact, prevents the Church from promoting its own agenda. Instead, it has to declare itself as a provider of social services and a defender of the common good (see: Mitrofanova 2019). We theorize that this position can indeed make the Church a stronger public actor. This position also has its weakness, however, in that it can prevent it from fulfilling the Christian mission.

Initially restricted material and human resources of faith-based organizations (FBOs) limited them to assisting people in their countries of origin. In the last decades, however, faith-based organizations have started contributing more to global socioeconomic development and humanitarian initiatives (see: Clarke 2006; Ter Haar and Ellis 2006; Hefferan et al. 2009; Deneulin and Rakodi 2011; Agensky 2013; Adogame et al. 2014; Tomalin 2015; Heist and Cnaan 2016; Papouras 2016; Prodromou and Symeonides 2016; Robert 2016; Heuser and Koehrsen 2020, etc.). Some FBOs form networks to extend their services to other countries ${ }^{1}$, while others provide local responses to global social concerns, including poverty, inequality, and underdevelopment. Faith-based social engagement in the sphere of global migration has become particularly visible in the aftermath of the 2015 "refugee crisis" (see: Permoser et al. 2010; Appleby 2011; Snyder 2012; Ager and Ager 2015; Bompani 2015; Kazmina 2017; Mattes 2017; Mavelli and Wilson 2017; Lyck-Bowen and Owen 2019; Schmiedel and Smith 2018; Kulska 2020; Lunkin 2020; Lyck-Bowen 2020, etc.). Most publications on the topic are empirical case studies, and their comparative discussion is impeded by national and regional peculiarities. The majority of authors agree that FBOs working with migrants and refugees often confront accusations of proselytizing their doctrines and having "secret agendas" (see: Reda 2012; Tittensor 2012; Agensky 2013, p. 471; Heist and Cnaan 2016, p. 239; Kazmina 2017, pp. 161, 173; Heuser and Koehrsen 2020, pp. 9-10, etc.). What makes the situation of the Russian Church unique is that it remains the only known FBO whose commitment to working with migrants is not motivated by humanitarian emergencies; from the very start the ROC declared its intention to become a systemic care provider for foreign workers in Russia.

\section{The ROC's Foundational Documents and Policy on Labor Migrants}

Russia is constitutionally a secular state, but, as the late Patriarch Aleksii once mentioned, "the Church is separated from state but ... [it] cannot be separated from society" (Patriarchia 2007). Founding principles of the ROC's public activity were blueprinted in "The Basis of the Social Concept" adopted by the 2000 Bishop's Council (detailed analysis of the document may be found in: van den Bercken 2002). The document specifies that the mission of the Church can be fulfilled "through good works aimed to improve the spiritual-moral and material condition of the world" (The Basis 2021, Article I.4), including "peacemaking on international, inter-ethnic, and civic levels, and promoting mutual understanding and co-operation among people, nations, and states" (ibid., Article III.8). The Church in the public sphere "enters into co-operation with the state, even if it is not Christian, as well as with various public associations and individuals, even if they do not identify themselves with the Christian faith" and sets no direct task "to have all converted to Orthodoxy as a condition for co-operation" (ibid., Article I.4).

The document did not examine missionary work; the latter is discussed separately in a statement of the Holy Synod "On the contemporary external mission" issued in July 2013. Without mentioning international migrants at all, this document provides some important clues to the policy of the Church on their sociocultural adaptation by making a difference between the internal and external mission. The internal mission concerns potential members of the Church, "including those who are baptized but not sufficiently enlightened in the Orthodox faith and who have no experience of participation in the sacramental life of the Church" (On the External Mission 2021). Potential members can also be those who are not baptized: in 2003 Patriarch Aleksii spoke about those being Orthodox Christians due to "the fact of baptism, or their faith, upbringing, culture, world vision, or a family tradition", and insisted that the Church "has no right to abandon its 
God-given pastoral responsibility for their destiny" (Religare 2003). The external mission addresses "those who are outside the Church... adherents of various beliefs and bearers of various worldviews, both religious and non-religious" (On the External Mission 2021). Regarding this form of mission, the ROC declares impossibility of proselytism not only of the followers of other religions, but also of their potential adherents. The external mission is seen as "indirect", or "the mission of presence", that is, "witness to the Gospel... through the expression of Orthodox position taken by the Church in various areas of public and cultural life", including social work and peacemaking (Ibidem).

This position of the Russian Church may seem hardly understandable from the viewpoint of many other Christian denominations, which feel free to spread the Word of God whenever they see the smallest opportunity for doing so. However, by differentiating the external and internal mission, the Church makes a valuable contribution to the preservation of peace in Russian society, where religion is commonly attributed to representatives of specific ethnicities, even in case they are personally non-religious: Orthodox Christianity to Russians and Ukrainians, Catholicism to Poles and Lithuanians, Islam to Tatars and Chechens, etc. (see: Curanović 2012, pp. 62-63). "Ethnic Muslims" is a frequently used term that covers all the members of ethnicities with Islamic historical backgrounds: Tatars, Tajiks, Uzbeks, peoples of the Caucasus, et al. (see: Krindatch 2014, p. 37). Terms like "ethnic Buddhists" (Kalmyks, Buryats) or "ethnic Lutherans" (Germans, Estonians) are less common but are fully intelligible in the Russian context ${ }^{2}$. Baptists and other legally recognized Protestant groups are seen within this paradigm as quasi-ethnicities, especially if being Protestant in the third, or fourth generation. Fragile interreligious and interethnicthese concepts can hardly be treated separately-peace in Russia is based, above all, on renouncing proselytism of ethnic groups not in your domain and on opposing to those who neglect these unwritten conventions, for example, to Jehovah's Witnesses, Mormons, or, in case of Islam, to radical Islamists (see: Kazmina 2015). Faiths, whose representatives observe the rules, are mentioned in the preamble to the 1997 Law on Freedom of Conscience and Religious Associations as religions having historical roots in the Russian Federation. These are Orthodoxy, Islam, Buddhism, Judaism, and some undefined "Christianity".

Having the above-said in mind, we conclude that sociocultural adaptation of presumably Muslim labor migrants carried serious consequences for the reputation of the Russian Orthodox Church and for its relations with both other "religions with historical roots" and the state. Some enthusiasts had started their adaptation projects earlier, but the idea of systemic church work in this sphere came up approximately in 2011, going hand in hand with changes in the government's position on sociocultural adaptation of foreign workers. The person behind the idea was Archpriest Vsevolod Chaplin (1968-2020), a permanent chair of the Synodal Department for Interactions between Church and Society in 2009-2015 $5^{3}$. As he later acknowledged in his memoirs, Fr. Chaplin authored most of the Basis of the Social Concept and other important church documents (Chaplin 2016, pp. $59,73)$. Striving to enforce the public role of the Church, he declared that: "if we do not set for us the tasks of changing society, we are worth nothing" (Danilova and Chaplin 2011). Some of his proposals shocked: to introduce all-Russian "modest" dress code, or to open Orthodox nightclubs (Ibidem). It was not always clear when he articulated the official position of the Church, and when expressed his private opinion. Despite this, journalists mostly presented everything he was saying as a church position.

In November 2011, speaking in the Civic Chamber of the Russian Federation, Fr. Chaplin linked sociocultural adaptation of international labor migrants to preventing tensions between migrants and the locals that could easily grow into an interethnic or interreligious violent conflict (Youtube 2011). From his viewpoint, which soon became the official position of the Church, the ROC's contribution into adaptation of migrants would pursue not its narrow parochial goals (such as attracting new believers), but the goals of peacekeeping and mediation, which are important for society as a whole. Later Patriarch Kirill explained that the Church had two reasons for being involved into sociocultural adaptation of foreign migrants. One of them was a Christian duty to help people in 
need. Another reason was that "lack of any understanding of the local culture, local language, local traditions, and customs [on the part of migrants] often provokes everyday collisions ... To correct this situation, the Church has joined this endeavor" (Russkaya Narodnaya Liniya 2013). Summarizing what has been said or written in this regard, the authors can indicate four basic aspects of peacekeeping mentioned by representatives of the Church in connection with its adaptation plans: (1) preventing violent conflicts between migrant workers and the locals; (2) preventing radicalization of labor migrants by Islamist agitators; (3) ensuring that everyday collisions with the newcomers will not be utilized by the extreme Russian nationalists; and (4) preventing hostility to Russia in the origin countries of migrants at its borders. From the start, the Church spoke about "adaptation", and not "integration" because the government promoted this terminology.

On 19 April 2013 Patriarch Kirill signed the Agreement on Collaboration between the Church and the Federal Migration Service of the Russian Federation providing for united effort in the sphere of sociocultural adaptation of labor migrants "on the basis of respect and observance of the traditional values and norms" (Patriarchia 2013, Article 2). The document does not mention any religion lessons, being focused on teaching the Russian language, culture, and law, on developing positive attitude to people of other ethnicities and faiths, on overcoming xenophobia, and promoting interethnic friendship, etc. (ibid., Article 3). Soon, most of the dioceses of the ROC signed similar agreements with their regional offices of the Migration Service.

To clarify the position of the Church, in November 2014 the Supreme Church Council adopted a short (about 7000 characters with blanks) document "The principles and directions for working with migrants in the Russian Orthodox Church", consisting of two small chapters. It repeats that the ROC's involvement into sociocultural adaptation is driven by its striving for peacekeeping (reference to Mathew 5:9). The mission of the Church is designated as "cultural" because it respects other religions with historical roots; therefore, labor migrants will learn about Orthodoxy only in the framework of «culture studies», without a perspective of conversion (Patriarchia 2014a). In the course of the year Fr. Vsevolod Chaplin further explained that "lessons offered to devout Muslims or to non-believers, are, of course, neither lessons of God's Law, nor any other special missionary project", although "we are not able to prevent conversion of many of them into Holy Orthodoxy" (Prikhozanin 2014). The last words might have sounded disturbing, and later he confirmed: "many of those who come to our society are Muslims. We have no intention to change their beliefs, but it is our duty to teach them culture and moral foundations of our society, because, without this knowledge, they will inevitably conflict with the local population" (Patriarchia 2014b). These and similar statements were needed to tranquilize both state authorities and leaders of the other faith-based communities, and to reassure them that the ROC had no intention of violating unwritten interreligious agreements on non-proselytisation. Islamic migrants too were the addressees of this message: they had to be persuaded that attending church adaptation classes would not be dangerous for their religious and ethnic identities. Later, the strategy proved to be successful because some local Islamic communities and associations of labor migrants enthusiastically supported the church adaptation initiative.

Ecclesiastical speakers contributed such enormous effort into pro-adaptation campaign that they neglected its anticipated side effects represented by immediate backlash from the nationalist Church members, extremely hostile to all non-Slavic migrants, be them Muslim or Christian (from Georgia, Armenia, Ossetia, or Abkhazia). Several days prior to signing the agreement with the Migration Service, Fr. Vsevolod Chaplin had called "not to be afraid of the new people in our society, but to do everything for them to become an organic part of this society" (Interfaks-Religiya 2013). This strong statement provoked Dmitrii Demushkin, a former skinhead and one of the extreme nationalist leaders of that time to renounce Fr. Chaplin's words by saying that: "we always thought that the task of the Russian Orthodox Church is to spread the Word of God and Orthodoxy, and not to adapt migrant religious communities in Russia" (Natsionalnyi Aktsent 2013). Another 
nationalist activist, Aleksandr Zhuchkovskii, member of the Movement Against Illegal Immigration (outlawed in 2011) and of the unregistered National Democratic Party, labeled the Church's involvement into adaptation of foreign immigrants as untimely, because "our Russian people are not yet Christianized and not enchurched" (Zhuchkovskii 2014, pp. 33, 43). Similar positions, often unarticulated, were and still are relatively common both for regular Church members, the clergy and even for the hierarchs. Nationalist opposition, however, was never powerful enough to have meaningful hampering effect on the church adaptation program, and the resistance of nationalists was limited to non-participating and being skeptical.

Another intra-church ideological platform had in the long run much large devastating potential for the adaptation initiative. This ideology is known as "ouranopolitism", or "heavenly citizenship" (see: Mitrofanova 2017). Its informal leader was Father Daniil Sysoev (1974-2009), son of a baptized Tatar mother. Undermining tacit interreligious conventions that concerned non-proselytism of "someone else's" ethnic groups, he wrote that "it was absurd that one can be Muslim, or Buddhist by birth" (Sysoev 2021) and even wore a recognizably Greek clerical hat (pill-shaped) instead of a Russian one (cylindrical) thus stressing non-national and non-ethnic nature of Orthodox Christianity. This concept of heavenly citizenship resulted in promoting proselytisation of Muslims, or "ethnic Muslims"-members of ethnic groups historically professing Islam, not necessarily foreign migrants. Approximately one month before his assassination (according to popular opinion, by some Islamic extremists $)^{4}$, Fr. Daniil publicized the baptism of a woman from Dagestan: "Kira, formerly a devout Muslim, became Daughter of God ... I am asking all my Orthodox friends to pray for Kira, baptized yesterday in our church, who should become the first in the conversion of Dagestan" (Sysoev 2009). This passionate preacher initiated several missionary projects, of which some were dedicated to catechizing labor migrants, and many people in the ROC remain under the influence of his ideas. Unlike nationalists, they welcomed church adaptation classes for migrants but could not accept a de facto ban on the Christian mission. Consequences of this situation will be discussed below.

\section{The Enlightenment Project: Successes and Failures of the Church Adaptation Courses}

"Enlightenment: linguistic and cultural adaptation of migrants", officially presented as a "church and public project" started in December 2012 in partnership with the Federal Migration Service and under supervision of Maksim Parshin, an employee of the Synodal Department for Interactions between Church and Society. It was the main initiative of the Department, and personally of Fr. Vsevolod Chaplin in the sphere of adaptation of foreign workers, with an aim to build all-Russian network of adaptation courses based at the dioceses of the Church (RIA Novosti 2013). Two years in sequence the project did win so-called presidential grants for noncommercial and nongovernmental organizations, contributing into development of civil society institutions. According to the rules of the grant competition, it was partly financed by state, and partly by the participating dioceses. The NGO that implemented the Enlightenment Project was the Russian Orthodox University of St. John the Divine.

The project started as a pilot test at six dioceses where local enthusiasts had already opened adaptation courses. These dioceses were: of Stavropol and Nevinnomyssk, of Pyatigorsk and Cherkessk, of Rostov-on-Don and Novocherkassk, of Khabarovsk, of Ekaterinodar and Kuban, and of Kaliningrad; later the dioceses of Sakhalin and the Kuril Islands, and of Saratov joined. In total, the project encompassed seven dioceses in six regions of Russia. By that moment nearly all the participating dioceses (except that of Ekaterinodar and Kuban) had signed agreements with their regional offices of the Migration Service. Several other dioceses declined invitations into the project, including the Diocese of Moscow, already having its own adaptation courses based on completely different principles (see below). The city of Moscow joined the network only closer to the end of the 
project, and was represented not by the diocese, but by a secular party (Foundation "Good Neighborhood", Dobrososedstvo).

The Enlightenment Project was to stimulate the dioceses to open more adaptation courses, because local administrators and teachers-previously often volunteer workersnow received financial support. Besides, it had to merge adaptation courses of all dioceses into a nationwide network with a single curriculum and its own course books. This network then was expected to become part of an all-Russian system of preparation for language and culture tests that would integrate courses initiated by religious and lay associations. Having the latter in mind, it was advertised as an entirely secular project (RIA Novosti 2013). One of the employees, a baptized Tatar ("ethnic Muslim"), had to conceal their identity using an invented Russian surname in public. Fr. Chaplin later confirmed that: "We are not organizing the courses, say, to convert Muslims into Orthodoxy. These people will remain Muslim. While teaching the Russian language, we'll speak with them not about faith, but exclusively about language, culture, traditions of our country, about our established morality norms" (Dozhd 2014). Dioceses mostly worked in partnership with local institutions for higher education (for example, the Diocese of Rostov-with the Southern Federal University, the Diocese of Kaliningrad-with the Immanuel Kant Baltic Federal University, etc.), and professional teachers of Russian as a foreign language worked out the language-related part of the curriculum and tests.

Some of the diocesan courses were successful. In Khabarovsk the regional office of the Migration Service helped in establishing connections between the diocese and owners of local businesses that employed foreign migrants. Administration of a stone quarry at Korfovskii company town organized lessons for workers during their working hours and even provided transportation for the teachers. Besides, the local Muslim community and leaders of ethnic diasporas encouraged labor migrants to enlist and provided, when needed, interpreters and venues. Another success story was Rostov-on-Don. Here, it was the local Afghani community (people who fled from Afghanistan after the withdrawal of the Soviet army) who asked the diocese to do adaptation classes for Afghani women. These people were, however, not foreign workers; they were either refugees or naturalized citizens of Russia. As for labor migrants, the regional office of the Migration Service assisted in reaching agreements on adaptation classes with "Rostov Foundry Plant, Ltd. (Rostov-on-Don, Russia)" and other enterprises that employed foreign workers.

Course books issued in the framework of the project encompassed three learning modules: language, culture and history, and law. Intended not just for diocesan classes, but also for a nationwide network of adaptation courses, the books are written in a secular manner, although not always consistently. Far from attempting to Russianize migrants, the authors tried to be as less Russocentric as possible and mentioned among representatives of Russian (obviously, not in the ethnic sense) culture people like a Russophone Kyrgyz writer Chinghiz Aitmatov. The book includes a text for reading practice "The traditional religions of Russia" that describes equity and peaceful coexistence of the four religions with historical roots mentioned above. Most attention is paid to Islam, and the topic is illustrated with a picture of the Kazan Kremlin where a mosque and an Orthodox church stand peacefully next to each other (Mitrofanova 2013, p. 17). The course book has an extensive chapter on religious culture (icon-painting, etc.), approached, as it was promised earlier, from the angle of culture studies. In fact, the first course book is dedicated not so much to specific Russian (folk) culture, but generally to the culture of late industrial society. For example, a text about women in Russian family and society warns the reader against possible misinterpretation of women's behavior and clothes: "in Russian culture a woman's direct glance to man, or her smile, have no special meaning and are not reprehensible" (Mitrofanova 2013, p. 47). Nothing about a "modest dress code" can be found in this book that is reminiscent of Soviet modernization practices in the Asian parts of the former empire.

The second course book, prepared by different authors, is similar in many aspects, but more focused on Central Asia. Friendship between ethnic groups in the Soviet period is illustrated here by reconstruction of Tashkent, the capital of Uzbekistan, after the 
devastating 1966 earthquake (Chaplin 2014, p. 166). The chapter about Russian culture in Central Asia is dedicated exclusively to church buildings and accompanied by their photographs (the author suggested that they would remind labor migrants about their home countries). The course draws parallels between Christianity and Islam and claims that "the Holy Scriptures of these religions have many things in common" (ibid., p. 168). References to Soviet modernization evaporated: the duty to respect women was mentioned, but the above-cited words about their behavior and smiling omitted. The cultural part too became less modernity-oriented, for example, a text about cinematograph had been cut out $^{5}$. Our impression is that the approach of the second course book is more conservative, probably, because Fr. Vsevolod Chaplin edited it himself.

Notwithstanding evident achievements of some dioceses, the Enlightenment Project, by its end in 2014, had not reached its strategic goal: no church-based adaptation network for labor migrants was in place. Some dioceses left the project (of Kaliningrad, of Pyatigorsk and Cherkessk, and of Ekaterinodar); others did not progress (only 22 migrants graduated for the whole period on the island of Sakhalin). Initially, the Enlightenment Project implied that its curriculum and course books would underlie a standard national test for labor migrants, which in 2014 did not yet exist. State, nevertheless, demonstrated no interest in the achievements of the project; and finally, a consortium of state universities developed standardized tests and a curriculum. The Church, or, at least, Fr. Chaplin planned to open its own network of testing centers for migrants (Interfaks-Religiya 2014), but it was never delivered.

The Enlightenment Project, in spite of its exceptionally good start, deteriorated due to many external and internal factors. One of them was Fr. Vsevolod Chaplin's resignation in December 2015 and his loss of ability to influence the Patriarchal policy. Besides, in April 2016 the Federal Migration Service was dismissed, and its functions related to adaptation of foreign migrants transmitted (in 2017) to the Federal Agency on Nationalities' Affairs. In their recruitment of students, dioceses heavily depended on good personal connections with the regional offices of the Migration Service able to mediate between local administrators of the courses and owners of businesses. Without their administrative support the diocesan courses have proven to be unattractive for labor migrants. Approximately for one year no specific government body was responsible for adaptation and this fact had a negative effect on the Church's plans as well. Unlike its predecessor, the Agency on Nationalities' Affairs did not sign cooperation agreement with the Church, nor with any of its dioceses. At the moment, the Agency supports some initiatives of faith-based non-commercial organizations, but none of them is dedicated to adaptation of foreign migrants.

Individual migrants that were not employed by large industrial facilities ignored diocesan courses and not considered them useful for passing a standardized test. The curriculum was too thick and overloaded with information about Russian culture and Orthodox Christianity that was not even included into the national test. A research conducted by Svetlana Riazanova (in collaboration with Aleksandr Chernykh) in the Perm Krai has shown that labor migrants mostly are not interested in being fully adopted to the local communities because even those working in Russia for years eventually intend to return to their countries of origin, and that Russian language proficiency is not crucial for their work strategies (Riazanova and Chernykh 2011); similar data has been collected in the other regions of Russia where foreign migrants are present (see, for example: Gasparishvili and Smolentseva 2012; Pozdeev and Arzamazov 2015; Oparin 2016; Ous 2019; Ushkin 2019; Pronina 2020, etc.). As a rule, Muslim labor migrants adopt to the new environment with a mediation of their own networks based on ethnicity or place of origin, without a necessity to learn extensive information about another religion. Even established local Islamic communities are rarely able to serve as intermediaries for adaptation, because foreign migrants evaluate their faith practices and customs as alien (see: Riazanova 2019), in particular those concerning interaction between men and women. 
In our opinion, the main cause of the project's non-fulfillment was an intra-church fundamental cleavage between the enthusiasts of adaptation convinced that diocesan courses must aim at spreading the Orthodox faith, including Muslims, and the church officials who promoted secular curriculum and forbade preaching Christianity to labor migrants. The enthusiasts often voluntarily worked with foreign migrants long before the Project Enlightenment, and even being employed by it, they sometimes openly renounced its ban on preaching and refused to speak about faith in the framework of "culture studies". For example, when commissionaires of the project arrived in the city of Taganrog (Diocese of Rostov) they found out that a young man teaching Russian history and culture to labor migrants envisions teaching religion as his central task and, not being a priest or monk, wears a cassock in class to be a visual symbol of Orthodoxy.

Besides, in mid-2010s systemic work with labor migrants was not a prerogative of Fr. Chaplin's department. The Synodal Missionary Department and the Missionary commission at the Diocesan Council of Moscow were promoting their own, catechization-based, concepts of adaptation. In 2013 Hieromonk Dmitrii (Pershin), a friend of late Fr. Daniil Sysoev and then the chair of the Moscow Missionary commission, initiated adaptation courses for labor migrants from Tajikistan. Although he never articulated his opposition to the tacit interfaith agreement on mutual non-proselytisation, adaptation for him was clearly a missionary undertaking. Speaking about the most acute missionary issues of the Russian Church, Hieromonk Dmitrii stressed that "we need to become comprehensible, and, in the perspective, to become dear to our migrants" but that conversation with them should be "honest" and without proselytism, unlike "some Protestant missionary projects" (Filippov and Pavlova 2015). Adaptation for Hieromonk Dmitrii was, first of all, sharing "religious meanings" as opposed to "culture studies" approach of the Enlightenment Project (Zaitseva 2016).

In August 2013 the Synodal Missionary Department in collaboration with the Belgorod Theological Seminary (having a missionary focus) offered its own blueprint of an adaptation network for foreign labor migrants. Its key concept was cultural mission seen as "the immersion of a migrant into the cultural context of the Orthodox tradition", in order "to facilitate the mission of conversion, for which the cultural mission is a preparatory stage" (Kontseptsiya 2013, p. 2). The document renounced Orthodox proselytism, while admitting that: "free conversion of the participants of the project is not rejected and would confirm that the program was successful" (ibid., p. 9). The blueprint spoke less about adaptation, or even integration of labor migrants, but rather about their full assimilation: terms like "anthropological correction of world outlook" and "ethnopsychological correction" were used (ibid, pp. 9,11). This Concept was widely discussed inside the Church, but never supported by the Patriarchate because of its evident violation of the tacit agreements on mutual non-proselytism between systemic Orthodox and Muslim organizations in Russia. The Enlightenment Project remained the only adaptation program that had been officially promoted nationwide, while other initiatives remained local and were, at best, tolerated by the Church leadership.

It was mostly due to this collision between the competing visions of adaptation that an attempt to build up a network of church courses was terminated. At the moment, no systemic adaptation of migrants is on the agenda of the Church, although labor migrants are continuously mentioned among those in need of social support. Nevertheless, some enthusiasts still work on sociocultural adaptation having Christian mission in mind. In 2018 Fr. Dionisii Grishkov opened in Moscow a free class of the Russian language for the children of foreign migrants. He also initiated a free medical practice for non-citizens of Russia (with the support of the Agency on Nationalities' Affairs) and other charity projects. None of them officially implies either sociocultural adaptation, or catechization, but Fr. Grishkov admitted that their side effect might be providing "a gradual opportunity to acquaint people with the fact that Christianity exists" (Youtube 2020). Under his supervision the Orthodox Book of Prayers was translated into the Tajik language (Patriarchia 2018). Similar projects are currently in progress in some dioceses where local enthusiasts still want to reach 
labor migrants. For example, in summer 2019 the Diocese of Khabarovsk implemented a «Friendship, Cross, and Crescent» project for children from migrant families to learn the Russian language and the foundations of Orthodox culture; officially it had no missionary aspect (Patriarchia 2019).

\section{Conclusions}

We would like to conclude by stating that sociocultural adaptation of foreign labor migrants that was initially an important part of the ROC's agenda moved over time to the periphery. State that in the beginning found the initiative promising enough to support it financially lost interest in the project as well. One of the reasons was its implementers' inability to achieve the intended objectives: the number of students remained insufficient, and no nationwide network was ever built. A more profound reason was a general cooling of church-state relations after the 2014 political crisis in Crimea. Patriarch Kirill never spoke out in support of Crimea joining the Russian Federation; he did not even attend a ceremonial meeting on 18 March 2014 addressed by the president of Russia. Up to now Orthodox parishes of Crimea officially remain "foreign" religious associations subordinated to the Ukrainian Orthodox Church of the Moscow Patriarchate, and their priests need work permissions.

At the moment, assistance to labor migrants is a subdivision of social work; only children from migrant families can have church-sponsored language and culture classes. An ambitious project of 2012-2014 to build a nationwide network of diocesan adaptation courses and testing centers for foreign labor migrants was unsuccessful. We think that the key factor of its breakdown was internal, namely, that this church initiative was declared "secular" and that its implementers continuously stressed that the project did not imply "teaching religion". Their reasons are fully understandable having in mind a tacit agreement on non-proselytism between the basic religious communities in Russia and the role this agreement plays in preserving domestic peace. This policy, however, remained puzzling for enthusiastic missionaries who welcomed Church-based sociocultural adaptation but only in accordance with their own model that implied teaching religion to migrants and their subsequent conversion as an indicator of success.

The missionary model was not acceptable for the Church, which presented itself as a responsible public actor. First, it would have devastating effect on relations between religious and ethnic groups in Russia and, most likely, provoke intergroup conflicts. Second, undermining domestic political stability would make the ROC an unreliable partner for state; in the long run this could lead to oppressing its public activities, including social and missionary work. Third, proselytism of adherents of other faiths is unacceptable also for many members of the Church. Therefore, the official ecclesiastical position as embodied in documents and in the Enlightenment Project was that church-sponsored adaptation of labor migrants was secular and pursued peacekeeping goals. This articulated secularism was enigmatic not just for the enthusiasts of missionary work, but also for most people of the Church.

Entering the public sphere of civil society as a provider of social services and an impartial (i.e., secular) conflict mediator, the Church can expect being appreciated, or, at least, tolerated by state and other civic associations. At the same time, given freedom of thought, conscience and religion, people in most cases join the Church not because they want to be engaged into performing socially useful secular tasks (this can be much easier achieved in lay civic associations) but because they want to achieve salvation there; and the Christian way of salvation implies spreading the Word of God. As a result, an ambitious program of adaptation was terminated because the Church's self-assigned role of a secular public actor came into collision with its task of preaching the Gospel.

Author Contributions: Conceptualization, S.R. and A.B.; Data curation, S.R.; Formal analysis, A.M., S.R. and A.B.; Investigation, S.R. and A.B.; Methodology, A.M. and S.R.; Project administration, A.M.; Resources, A.B.; Writing-original draft, A.M. All authors have read and agreed to the published version of the manuscript. 
Funding: This research received no external funding.

Institutional Review Board Statement: Not applicable.

Informed Consent Statement: Not applicable.

Data Availability Statement: Not applicable.

Conflicts of Interest: The authors declare no conflict of interest.

\section{Notes}

1 International Orthodox Christian Charities (IOCC) is the largest Orthodoxy-based humanitarian relief and development network operating under the aegis of the Assembly of Canonical Orthodox Bishops of the United States of America. Its programs include assistance to refugees worldwide. The Russian Orthodox Church is also a participant of an international ACT (Actions by Churches Together) Alliance, member of the Global Forum on Migration and Development.

2 Without going into details about the confrontation between constructivists and primordialists, we would like to mention that although a Soviet practice of indicating people's "nationality" (i.e., ethnicity) in passports was terminated in 1992, most of Russian citizens are aware of their ethnicity.

3 In the end of 2015 the department was liquidated; Fr. Vsevolod, who had not received a new position, served as a dean of a Moscow parish up to his premature death.

$4 \quad$ Fr. Daniil Sysoev was mortally wounded on 19 November 2009 by an unknown man wearing a medical mask. The crime has never been solved, although Fr. Daniil several times admitted getting hate calls from Islamic radicals.

5 It was known at the moment that the standardized national test would be focused on Russian history, not on culture.

\section{References}

Adogame, Afe, Janice McLean, and Jeremiah Anderson. 2014. Engaging the World: Christian Communities in Contemporary Global Societies. Oxford: Regnum Studies in Mission.

Agensky, Jonathan C. 2013. Dr Livingstone, I Presume? Evangelicals, Africa and Faith-Based Humanitarianism. Global Society 27: 454-74. [CrossRef]

Ager, Alastair, and Joey Ager. 2015. Faith, Secularism, and Humanitarian Engagement: Finding the Place of Religion in the Support of Displaced Communities. London: Palgrave Macmillan.

Appleby, J. Kevin. 2011. The Role of The Catholic Church in Immigrant Integration. The Review of Faith and International Affairs 9: 67-70. [CrossRef]

Bompani, Barbara. 2015. Local Religious Organisations Performing Development: Refugees in the Central Methodist Mission in Johannesburg. Journal of International Development 27: 197-212. [CrossRef]

Casanova, José. 1994. Public Religions in the Modern World. Chicago: University of Chicago Press.

Chaplin, Vsevolod, ed. 2014. Russkii Yazyk, Istoriya o Osnovy Zakonodatelstva Rossii [Russian Language, History and Foundations of Law in Russia]. Rostov-on-Don: Foundation.

Chaplin, Vsevolod. 2016. Vera i Zhizn [Faith and Life]. Moscow: Algoritm.

Cherepanova, Mariya, and Svetlana Maksimova. 2019. Musulmane v rossiiskom pogranichiye: Adaptatsiya zhenshchin-migrantov [Muslim in Russia's borderland: Adaptation of migrant women]. Society and Security Insights 2: 52-64.

Clarke, Gerard. 2006. Faith Matters: Faith-Based Organisations, Civil Society and International Development. Journal of International Development 18: 835-48. [CrossRef]

Curanović, Alicja. 2012. The Religious Factor in Russia's Foreign Policy. Contemporary Russia and Eastern Europe. London: Routledge.

Curanović, Alicja. 2019. The Russian Orthodox Church, human security, migration and refugees. In Forced Migration and Human Security in the Eastern Orthodox World. Edited by Lucian Leustean. London: Routledge, pp. 66-105.

Danilova, Anna, and Vsevolod Chaplin. 2011. Vazhno vsyo! [Everything is important!]. Pravoslavie i Mir. May 3. Available online: https:/ / www.pravmir.ru/vazhno-vse-prot-vsevolod-chaplin-o-diskussiyax-vokrug-dress-koda-nochnyx-klubov-ipravoslavii-v-smi/ (accessed on 5 October 2021).

Deneulin, Séverine, and Carole Rakodi. 2011. Revisiting Religion and Development: 30 Years On. World Development 39: 45-54. [CrossRef]

Dozhd. 2014. Protoierei Chaplin o sovmestnom proekte s FMS: «My ne o vere migrantam budem rasskazyvat» [Archpriest Chaplin about a joint project with FMS: «We will speak with migrants not about faith»]. Dozhd. July 3. Available online: https:/ /tvrain.ru/teleshow/here_and_now / protoierej_chaplin_o_sovmestnom_proekte_s_fms_my_ne_o_vere_migrantam_ budet_rasskazyvat-371521/ (accessed on 5 October 2021).

Drobizheva, Leokadiya. 2010. Integratsionnye protsessy i adaptatsiya migrantov v rossiiskom obshchestve [Processes of integration and adaptation of migrants in Russian society]. Vestnik Rossiiskoi Natsii 4-5: 88-111. 
Filippov, Aleksandr, and Ekaterina Pavlova. 2015. Ieromonakh Dmitrii (Pershin: Pravoslavie bez mordobitiya nevozmozhno bez vysshei shkoly [ Hieromonk Dmitrii (Pershin): Orthodoxy without violence is impossible unless higher education is involved]. Pravoslavie i Mir. July 13. Available online: https:/ / www.pravmir.ru/ieromonah-dmitriy-pershin-pravoslavie-bez-mordobitiyanevozmozhno-bez-vyisshey-shkolyi/ (accessed on 5 October 2021).

Gasparishvili, Aleksandr, and Anna Smolentseva. 2012. Trudovye migranty iz Centralnoi Azii v Moskve: Voprosy adaptatsii [Labor migrants from Central Asia in Moscow: The issues of adaptation]. Vestnik Rossiiskogo universiteta druzhby narodov. Seriya: Sociologiya 2: 56-64.

Hämmerli, Maria, and Jean-François Mayer, eds. 2014. Orthodox Identities in Western Europe: Migration, Settlement and Innovation. London: Routledge.

Hefferan, Tara, Julie Adkins, and Laurie Occhipinti, eds. 2009. Bridging the Gaps: Faith-Based Organizations, Neoliberalism, and Development. Lanham: Lexington Books.

Heist, Dan, and Ram A. Cnaan. 2016. Faith-Based International Development Work: A Review. Religions 7: 19. [CrossRef]

Heuser, Andreas, and Jens Koehrsen, eds. 2020. Faith-Based Organizations in Development Discourses and Practice. Abingdon and New York: Routledge.

Interfaks-Religiya. 2013. Migrantov v Rossii nuzhno ne boyatsya, a integrirovat, schitayut v Tserkvi [In Russia we should not be afraid of migrants, but to integrate them, the Church thinks]. Interfaks-Religiya. April 8. Available online: http://www.interfax-religion. $\mathrm{ru} /$ ?act=news\&div=50711 (accessed on 5 October 2021).

Interfaks-Religiya. 2014. V Tserkvi khotiat zaniatsya testirovaniem migrantov na znanie yazyka i zakonov Rossii [The Church wants to start testing migrants on language skills and law of Russia]. Interfaks-Religiya. November 12. Available online: http: / / www.interfax-religion.ru/?act=news\&div=57014 (accessed on 5 October 2021).

IOM. 2021. Key Migration Terms. International Organization for Migration, September 12, Available online: https://www.iom.int/keymigration-terms (accessed on 5 October 2021).

Kazmina, Olga E. 2015. Missionerstvo i prozelitizm kak kategorii religioznogo diskursa i akademicheskogo analiza [Mission and proselytism as categories of religious discourse and academic analysis]. Vestnik Antropologii 2: 48-65.

Kazmina, Olga E. 2017. Sluzha Bogu, pomogaya blizhnemu, sotrudnichaya s gosudarstvom. Sotsialnaya rabota khristianskikh organizatsii SShA sredi bezhentsev [Serving God, Helping a Neighbour, and Cooperating with the State. US Christian Organisations' Social Work Among Refugees]. Sibirskie Istoricheskie Issledovaniya 4: 149-78. [CrossRef]

Kontseptsiya. 2013. Kontseptsiya pilotnogo proekta Kulturnaya missiya sredi trudovykh migrantov [The concept of a pilot project "Cultural mission among labor migrants"]. Moscow-Belgorod. The authors' archive.

Krindatch, Alexey. 2014. Religion, Public Life and the State in Putin's Russia. Occasional Papers on Religion in Eastern Europe 26: 28-67. Available online: https:/ / digitalcommons.georgefox.edu/ree/vol26/iss2/5 (accessed on 5 October 2021).

Kulska, Joanna. 2020. Religious Engagement and the Migration Issue: Towards Reconciling Political and Moral Duty. Religions 11: 236. [CrossRef]

Ledenyova, Viktoriya, and Bakytzhan Begasilov. 2021. Vliyanie religioznogo faktora na protsessy integratsii migranyov-musulman v Rossii [The influence of the religious factor on the process of integration of Muslim migrants in Russia]. Voprosy Upravleniya 1: 118-30.

Leustean, Lucian N., ed. 2019. Forced Migration and Human Security in the Eastern Orthodox World. London: Routledge.

Lunkin, Roman. 2019. Strategiya raboty religioznykh obiedinenii s migrantami: Ot sotsianoi adaptatsii k missii [The strategy of religious associations' work with migrants: From social adaptation to mission]. Nauchno-Analiticheskii Vestnik IE RAN 1: 77-83.

Lunkin, Roman. 2020. Tserkvi v Politike i Politika v Tserkvyakh. Kak Sovremennoye Khristianstvo Menyaet Evropeiskoye Obshchestvo [Churches in Politicis and Politics in Churches. How Contemporary Christianity Changes European Society]. Moscow: IE RAN, St. Petersburg: Nestor-istoriya.

Lyck-Bowen, Majbritt. 2020. Multireligious Cooperation and the Integration of Muslim Migrants in Sweden. Annals of the American Academy of Political and Social Science 690: 168-74. [CrossRef]

Lyck-Bowen, Majbritt, and Mark Owen. 2019. A Multi-Religious response to the Migrant Crisis in Europe: A Preliminary Examination of Potential Benefits of Multi-religious Cooperation on the Integration of Migrants. Journal of Ethnic and Migration Studies 45: 21-41. [CrossRef]

Mattes, Astrid. 2017. Part of the Problem or of the Solution? The Involvement of Religious Associations in Immigrant Integration Policy. Osterreichische Zeitschrift fur Politikwissenschaft 46: 43-58. [CrossRef]

Mavelli, Luca, and Erin K. Wilson, eds. 2017. The Refugee Crisis and Religion. London: Rowman and Littlefield International.

Mitrofanova, Anastasia, ed. 2013. Osnovy Russkogo Yazyka i Kultury [Foundations of Russian Language and Culture]. Moscow: Pero.

Mitrofanova, Anastasia. 2017. L'Église orthodoxe russe: Nationalisme ou universalité? Hérodote: Revue de Géographie et de Géopolitique 166/167: 99-114. [CrossRef]

Mitrofanova, Anastasia. 2019. Orthodox Actors and Equal Opportunities Policies in The Republic of Moldova in the Context of the Transformation of Post-Soviet Societies. Approaching Religion 9: 96-112. [CrossRef]

Natsionalnyi Aktsent. 2013. Natsionalist Demushkin Obespokoen Zhelaniem RPTs Zanimatsya Adaptatsiei Migrantov [Nationalist Demushkin Is Concerned about the ROC's Intention to Deal with Adaptation of Migrants]. Posted by Vixey. Natsionalnyi Aktsent. April 9. Available online: https:/ / nazaccent.ru/content/7418-nacionalist-demushkin-obespokoen-zhelaniem-rpc-zanimatsya. html (accessed on 5 October 2021). 
Olimov, Muzaffar, and Saodat Olimova. 2019. Transformatsiya identichnosti v migratsii: Etnichnost i religiya [Transformation of identity in migration: Ethnicity and religion]. Vestnik Tomskogo gosudarstvennogo universiteta. Istoriya 59: 158-66.

On the External Mission. 2021. On the external mission of the Russian Orthodox Church today. Official translation. The Russian Orthodox Church. Department of External Church Relations. No date. Available online: https://old.mospat.ru/en/documents/ o-sovremennojj-vneshnejj-missii-russkojj-pravoslavnojj-cerkvi/ (accessed on 5 October 2021).

Oparin, Dmitrii. 2016. «Mestnye» i «priezzhie» na Yamale: Socialnye granitsy i variativnost migratsionnogo opyta ["Locals" and "Newcomers" in Yamal: Social borders and varieties of migration experience]. Sibirskie Istoricheskie Issledovaniya 4: 108-30. [CrossRef] [PubMed]

Ous, Marina. 2019. Etnicheskie anklavy kak forma integratsii inokulturnykh soobshchestv v Khabarovskom krae: Sotsiologicheskii aspect [Ethnic enclaves as a form of integration for other culture communities in the Khabarovsk Krai: A sociological aspect]. Vlast i Upravleniye na Vostoke Rossii 4: 156-63.

Papouras, Pascalis. 2016. Faith Through Deeds: Case Studies of a Faith-Based Humanitarian Organization. The Review of Faith and International Affairs 14: 51-57. [CrossRef]

Patriarchia. 2007. Tserkov otdelena ot gosudarstva, no ne ot obshchestva [The Church is Separated from State, not from Society. Interview with Patriarch Aleksii II]. Official Web-Site of the Moscow Patriarchate. December 13. Available online: http://www. patriarchia.ru/db/text/337720.html (accessed on 5 October 2021).

Patriarchia. 2013. Soglasheniye o vzaimodeistvii Russkoi Pravoslavnoi Tserkvi i Federalnoi Migratsionnoi Sluzhby Rossii [Agreement on cooperation between the Russian Orthodox Church and the Federal Migration Service of Russia]. Official web-site of the Moscow Patriarchate. April 19. Available online: http://www.patriarchia.ru/db/text/2917828.html (accessed on 5 October 2021).

Patriarchia. 2014a. Printsipy i napravleniya raboty s migrantami v Russkoi Pravoslavnoi Tserkvi [Principles and directions of work with migrants in the Russian Orthodox Church]. Official web-site of the Moscow Patriarchate. November 20. Available online: http:/ / www.patriarchia.ru/db / text/460673.html (accessed on 5 October 2021).

Patriarchia. 2014b. Net liubvi bez pravdy [There is no love without truth. Interview with Fr.Vsevolod Chaplin]. Official Web-Site of the Moscow Patriarchate. September 30. Available online: http:/ / www.patriarchia.ru/db/text/3769807.html (accessed on 5 October 2021).

Patriarchia. 2018. Pravoslavnyi molitvoslov pereveden na tadzhikskii yazyk [Orthodox Book of Prayers is translated into Tadjik]. Official Web-Site of the Moscow Patriarchate. July 7. Available online: http:/ /www.patriarchia.ru/db/text/5232962.html (accessed on 5 October 2021).

Patriarchia. 2019. V Khabarovskoi eparkhii zavershilsya proekt po obucheniyu detei migrantov russkomu yaziku i oznakomleniyu s pravoslavnoi kulturoi [In the Diocese of Khabarovsk a project has been completed on teaching the Russian language and Orthodox culture to children of migrants]. Official Web-Site of the Moscow Patriarchate. July 1. Available online: http:/ / eparchia. patriarchia.ru/db/text/5462673.html (accessed on 5 October 2021).

Permoser, Julia Mourão, Sieglinde Rosenberger, and Kristina Stoeckl. 2010. Religious Organisations as Political Actors in the Context of Migration: Islam and Orthodoxy in Austria. Journal of Ethnic and Migration Studies 36: 1463-81. [CrossRef]

Pozdeev, Igor, and Aleksei Arzamazov. 2015. Uzbeki v Rossii: Praktiki adaptacii v inokulturnoi srede [Uzbeks in Russia: Adaptation practices in the other culture's environment]. Vestnik Rossiiskogo universiteta druzhby narodov. Seriya: Sociologiya 15: 123-36.

Prikhozanin. 2014. Pochemu Tserkov rabotaet s migrantami? [Why the Church works with migrants?]. Prikhozhanin. May 31. Available online: https:/ / prihozhanin.msdm.ru/home/podumat/o-zhizni/714-pochemu-tserkov-rabotaet-s-migrantami.html (accessed on 5 October 2021).

Prodromou, Elizabeth H., and Nathanael Symeonides. 2016. Orthodox Christianity and Humanitarianism: An Introduction to Thought and Practice, Past and Present. The Review of Faith and International Affairs 14: 1-8. [CrossRef]

Pronina, Tatiyana. 2020. Migratsiya v sovremennoi Rossii i religioznyi factor [Migration in contemporary Russia and the religious factor]. Vestnik Leningradskogo gosudarstvennogo universiteta imeni A. S. Pushkina 3: 225-40.

Rambler. 2021. V Rossii stalo na 35\% menshe trudovykh migrantov [In Russia there has become 35\% less labor migrants]. Rambler. June 2. Available online: https:/ / news.rambler.ru/sociology / 46542577/?utm_content=news_media\&utm_medium=read_more\& utm_source=copylink (accessed on 5 October 2021).

Reda, Ayman. 2012. Religious Charities and Government. Funding International Advances in Economic Research 18: 331-42. [CrossRef]

Regnum. 2021. Nazvano chislo obuchayushchikhsya v Rossii inostrannykh studentov [The number of foreign students who study in Russia is published]. Regnum. August 4. Available online: https://regnum.ru/news/cultura/3337095.html (accessed on 5 October 2021).

Religare. 2003. Vyzov veka sego [The challenge of this century. Interview with Patriarch Aleksii II]. Religare. May 6. Available online: http:/ / www.religare.ru/2_3833.html (accessed on 5 October 2021).

RIA Novosti. 2013. RPTs zapuskaet programmu po sistemnoi adaptatsii trudovykh migrantov [The ROC launches a program on systemic adaptation of labor migrants]. RIA Novosti. April 8. Available online: https:// ria.ru/20130408/931522061.html (accessed on 5 October 2021).

Riazanova, Svetlana. 2019. Migrants and Conflicts within the Local Ummah of the Perm Krai: A Playing Card or a Social Actor? Stanovništvo 57: 97-111. [CrossRef]

Riazanova, Svetlana, and Aleksandr Chernykh. 2011. Immigrantskie obshchiny musulman. The authors' archive. 
Riazanova, Svetlana, and Aleksandr Chernykh. 2012. Migratsionnye protsessy sredi musulman kak faktor formirovaniya konfessionalnoi kartiny regiona [Migration processes among Muslims as a factor shaping the confessional map of a region]. Nauchnyi Ezhegodnik Instituta Filosofii i Prava Uralskogo Otdeleniya RAN 12: 379-82.

Robert, Dana L. 2016. Orthodoxy and Humanitarianism: Realities, Resources, and Future Research. The Review of Faith and International Affairs 14: 58-65. [CrossRef]

Russkaya Narodnaya Liniya. 2013. Patriarkh Kirill: «Tserkvi neobkhodimo svoevremenno i motivirovanno uchastvovat v rabote s migrantami» [Patriarch Kirill: «The Church needs to participate in work with migrants timely and with strong motivation]. Russkaya Narodnaya Liniya. April 20. Available online: https://ruskline.ru/news_rl/2013/04/20/patriarh_kirill_cerkvi_neobhodimo_ svoevremenno_i_motivirovanno_uchastvovat_v_rabote_s_migrantami/ (accessed on 5 October 2021).

Schmiedel, Ulrich, and Graeme Smith, eds. 2018. Religion in the European Refugee Crisis. London: Palgrave Macmillan.

Snyder, Susanna. 2012. Asylum-Seeking, Migration and Church. Burlington: Ashgate.

Starostin, Aleksei. 2011. Politika DUM Rossii po sotsiokulturnoi adaptatsii migrantov [The policy of the Spiritual Department of Muslims in Russia on sociocultural adaptation of migrants]. Islam v Sovremennom Mire 3-4: 36-41.

Starostina, Yuliya. 2019. FSB vpervye za 20 let raskryla chislo priekhavshikh rabotat inostrantsev [First time in 20 years the FSB has published the number of foreigners who came to work]. August 16. Available online: https://www.rbc.ru/economics/16/08/20 19/5d5560979a7947af4fa8a883 (accessed on 5 October 2021).

Stoeckl, Kristina. 2014. Orthodox churches and migration. In Eastern Christianity and Politics in the Twenty-First Century. Edited by Lucian Leustean. London and New York: Routledge, pp. 721-36.

Sysoev, Daniil. 2009. Nebesnaya radost! [Heavenly joy!]. Livejournal. September 27. Available online: http://pr-daniil.livejournal. com/53341.html (accessed on 5 October 2021).

Sysoev, Daniil. 2021. Pochemu ty eshcho ne krestilsya? [Why aren't you baptized yet?]. Azbuka. No date. Available online: https:/ / azbyka.ru/pochemu-ty-eshhe-ne-krestilsya\#a_z7 (accessed on 5 October 2021).

Ter Haar, Gerrie, and Stephen Ellis. 2006. The role of Religion in Development: Towards a New Relationship Between the European Union and Africa. The European Journal of Development Research 18: 351-67. [CrossRef]

The Basis. 2021. The Basis of the Social Concept. Official translation. The Russian Orthodox Church. Department of External Church Relations. No date. Available online: https:/ / old.mospat.ru/en/documents/social-concepts/ (accessed on 5 October 2021).

Tittensor, David. 2012. The Gülen Movement and the Case of a Secret Agenda: Putting the Debate in Perspective. Islam and Christian-Muslim Relations 23: 163-79. [CrossRef]

Tomalin, Emma, ed. 2015. The Routledge Handbook of Religions and Global Development. London and New York: Routledge, Taylor and Francis Group.

Tretiyakova, Marina. 2021. Nazvano chislo bezhentsev v Rossii [The number of refugees in Russia is published]. Parlamentskaya gazeta. March 23. Available online: https:/ / www.pnp.ru/politics/nazvano-chislo-bezhencev-v-rossii.html (accessed on 5 October 2021).

Ushkin, Sergei. 2019. Prinimayushchee soobshchestvo i inostrannye migranty: Regionalnye praktiki adaptacii [Receiving community and foreign migrants: Regional adaptation practices]. Upravlencheskoe Konsultirovanie 12: 191-201. [CrossRef]

van den Bercken, Wil. 2002. A Social Doctrine for the Russian Orthodox Church. Exchange 31: 373-85. [CrossRef]

Vinokurova, Anna, and Anna Ardalianova. 2017. Etnolonfessionalnye aspekty sotsianoi adaptatsii trudovykh migrantov v Primorskom krae [Ethnoconfessional aspects of social adaptation of labor migrants in Primorsky Krai]. Diskurs 12: 134-41.

WCIOM. 2019. Pravoslavnaya vera i tainstvo kreshcheniya [Orthodox faith and the sacrament of baptism]. WCIOM. August 14. Available online: https:/ / wciom.ru/analytical-reviews/analiticheskii-obzor/pravoslavnaya-vera-i-tainstvo-kreshheniya (accessed on 5 October 2021).

Youtube. 2011. Vsevolod Chaplin o migrantakh [Vsevolod Chaplin on migrants]. Obshchestvennaya palata Rossiiskoi Federatsii. November 16. Available online: https://www.youtube.com/watch?v=JSfz7xNrgeg (accessed on 5 October 2021).

Youtube. 2020. Opyt missii sredi migrantov i inostrantsev l o. Dionisii Grishkov [An experience of mission for migrants I Fr. Dionisii Grishkov]. Daniilmission. January 14. Available online: https://www.youtube.com/watch?v=nmCe1kLrFPc (accessed on 5 October 2021).

Zaitseva, Yuliya. 2016. Ieromonakh Dmitrii (Pershin) vodit migrantov v ikonnye zaly Tretiyakovki [Hieromonk Dmitrii (Pershin) takes migrants to the icons, halls of the Tretiyakov Gallery]. Blagovest-Info. June 7. Available online: http://blagovest-info.ru/index. php?ss $=2 \& s=3 \& i d=68254$ (accessed on 5 October 2021).

Zhuchkovskii, Aleksandr. 2014. «Pervaya pyatiletka» Patriarkha Kirilla. Voprosy Natsionalizma 1: $33-43$. 